\title{
Pola Komunikasi Keluarga Anggota TNI-AD
}

\author{
Nadira Dwi Yuna Amanda*, Dadan Mulyana
}

Prodi Public Relation, Fakultas Ilmu Komunikasi, Universitas Islam Bandung, Indonesia.

*nadiradwi1698@gmail.com, dadanmulyana1962@gmail.com

\begin{abstract}
This study aims to see how the pattern of communication among military members from the perspective of family communication. The background of the research is a case study of the process of forming a communication pattern for children whose parents are soldiers (TNI) and are left behind by their parents who require long-distance communication. The method used in this research is qualitative with a case study approach. In general, qualitative research is based on the traditional case study method, the research process of understanding case studies with community issues as the object. Data collection techniques used in this study were observation, interviews, library research, and use of documents. The data analysis techniques taken are data simplification, data presentation, verification, and drawing conclusions from the sources. The selection of sources was determined from several soldiers' children who had long-distance relationships with their parents. From the results of the study, it can be seen how communication between parents and children in the TNI family. Every parent has a positive way of communicating with children and expects positive results as well, therefore good relations will be established between children and parents, and vice versa.
\end{abstract}

Keywords: Family Communication, pattern, TNI family, personality.

Abstrak. Penelitian ini bertujuan melihat bagaimana pola komunikasi dalam kalangan anggota militer dari perspektif komunikasi keluarga. Latar belakang penelitian adalah studi kasus proses terbentuknya pola komunikasi anak yang orang tuanya berstatus prajurit (TNI) dan ditinggal tugas oleh orang tuanya yang mengharuskan memiliki komunikasi jarak jauh. Metode yang digunakan dalam penelitian ini adalah kualitatif dengan pendekatan studi kasus. Secara umum, penelitian kualitatif didasarkan pada metode tradisional studi kasus, proses penelitian pemahaman studi kasus dengan isuisu masyarakat sebagai objeknya. Teknik pengumpulan data yang digunakan dalam penelitian ini adalah observasi, wawancara, penelusuran kepustakaan, dan penggunaan dokumen. Teknik anaslisis data yang diambil yaitu penyederhanaan data, penyajian data, verifikasi, dan penarikan kesimpulan dari narasumber. Penentuan narasumber ditentukan dari beberapa anak tentara yang mengalami hubungan jarak jauh dengan orang tua. Dari hasil penelitian dapat diketahui cara komunikasi antara orang tua dengan anak dalam keluarga TNI. Setiap orang tua mempunyai cara yang positif untuk komunikasi dengan anak dan mengharapkan hasil yang positif juga, maka dari itu akan terjalinnya hubungan baik antar anak dengan orang tua, begitu pula sebaliknya.

Kata Kunci: Komunikasi Keluarga, pola, Keluarga TNI, kepribadian. 


\section{A. Pendahuluan}

Menurut Undang-Undang Republik Indonesia Nomor 34 Tahun 2004 Tentang Tentara Nasional Indonesia bahwa Tentara Nasional Indonesia sebagai alat pertahanan Negara Kesatuan Republik Indonesia, bertugas melaksanakan kebijakan pertahanan negara untuk menegakkan kedaulatan negara, mempertahankan keutuhan wilayah, dan melindungi keselamatan bangsa, menjalankan operasi militer untuk perang dan operasi militer selain perang, serta ikut secara aktif dalam tugas pemeliharaan perdamaian regional dan internasional. Kewajiban dari seorang TNI sebagai abdi negara yang bersifat nomaden dan sering meninggalkan keluarga untuk melaksanakan tugas, terkadang berefek kepada komunikasi keluarga yang mempengaruhi karakter anak. Dikarenakan minimnya interaksi atau pola komunikasi di kalangan keluarga TNI Desta '89, menurut studi literatur dan wawancara yang saya lakukan terhadap anggota keluarga. Penting untuk di bahas karena hal yang saya rasakan sebagai anak TNI belum tentu sama dengan anak lainnya. Pemilihan pola asuh orang tua juga berbeda-beda pada umumnya, tetapi rata-rata anggota TNI yang memiliki dan merasakan sikap otoriter pada masa pendidikannya juga ingin anaknya merasakan pola tersebut. Adanya sebab dan akibat dari suatu pola yang diberikan, artinya tentara yang biasanya bersikap otoriter terhadap keluarga, tetapi sebenarnya tidak seperti itu, munculah isu-isu social yang ingin kita bahas disini. Keluarga merupakan lingkungan sosial dan memiliki aturan tersendiri sesuai dengan pilihan model parenting keluarga.

Menurut saya pola komunikasi yang orang tua saya ambil sudah tepat karena saya sendiri merasa tidak adanya paksaan dan juga tidak sepenuhnya dibebaskan, tetapi tidak dengan anggota keluarga lain ataupun keluarga tentara lainnya. Dalam wawancara singkat yang menanyakan tentang pola asuh apa yang orang tua saya ambil adalah demokratis terkontrol. Karena demokratis memiliki keseimbangan berendapat, pengambilan keputusan dan juga mengatur diri sendiri, bagaimana menyikapinya, sehingga karakter yang dihasilkan bisa mandiri dan juga dewasa. Inti dari masalah yang ingin dibahas apakah pola asuh itu selalu mempengaruhi karakter anak, dan faktor yang penghambat penerapan pola asuh itu sendiri Baumrind, D.

Pengenalan dan pendidikan yang diterima oleh anak melalui keluarga diharapkan dapat membentuk suatu karakter dan perilaku anak yang sesuai yaitu memiliki karakter yang baik dan sesuai harapan. Dikarenakan pengaruh orang tua ataupun lingkungan keluarga yang ditemui setiap harinya dan secara terus-menerus, maka komunikasi antarpersona dalam keluarga diharapkan terjalin dengan baik dan dapat dicerna baik oleh anak-anak. Komunikasi yang dilakukan selama beberapa saat dengan jangka waktu yang lama, dapat membentuk beberapa karakter yang berbeda-beda. Adapun orang tua dari anggota TNI lainnya yang mengganggap bahwa kebutuhan keluarga hanya sekedar materi saja, yang terkadang lupa akan kebutuhan atau pentingnya komunikasi antarpersonal atau komunikais keluarga. Beberapa sikap seperti itu dapat mempengaruhi karakter anak, yang terkadang menjadikan anak tersebut tidak dekat dengan orang tuanya atau bahkan menjadi anak tersebut memiliki karakter yang manja. Diana Baumrind. Dimana tugas TNI sendiri beberapanya adalah Operasi Militer kedaerah-daerah yang rawan perang. TNI memiliki tugas pokok yaitu menegakkan kedaulatan negara, mempertahankan keutuhan wilayah Negara Kesatuan Republik Indonesia yang berdasarkan Pancasila dan UUD 1945, serta melindungi segenap bangsa dan seluruh tumpah darah Indonesia dari segala macam ancaman dan gangguan disampaikan Panglima TNI Marsekal TNI Hadi Tjahjanto, S.I.P.

Dalam hal ini saya lebih membahas tentang bagaimana pola komunikasi itu tetap terjalin dan berjalan sesuai dengan yang diharapkan, walaupun adanya jarak orang tua dengan anak. Penugasan atau operasi yang dilakukan secara mendadak dan mewajibkan seorang anggota militer wajib mengikuti perintah atasan yang sudah sesuai dengan surat keputusan yang ada.

Berdasarkan latar belakang masalah di atas, peneliti merumuskan masalah yaitu "Bagaimana Pola Komunikasi Keluarga TNI Desta '89 (Studi Kasus Long Distance Relationship (LDR) dengan Orang Tua di Kalangan Keluarga TNI Desta adalah sebagai berikut: 
1. Bagaimana pola komunikasi dengan orang tua anda selama ini berikan?

2. Bagaimana komunikasi yang dilakukan oleh orang tua anda selama ditinggal?

3. Mengapa komunikasi keluarga penting dilakukan dalam kalangan keluarga TNI Desta' 89 ?

\section{B. Metodologi Penelitian}

Penelitian ini menggunakan metode kualitatif dan metode studi kasus. Studi kasus adalah studi metodologis yang memiliki tujuan untuk memahami sisi dari perspektif orang yang mengalami kondisi dari perspektif yang terkait dengan hakikat dan makna pengalaman manusia. Studi kasus berfokus pada objek tertentu, yang ditetapkan sebagai kasus untuk dikaji secara mendalam agar dapat menemukan realitas di balik fenomena tersebut. Karena yang nampak itu tidak nyata (realita).

Metode penelitian yang digunakan dalam penelitian ini adalah metode penelitian kualitatif, dikarenakan ingin lebih mendalami secara proses pemahaman saat wawancara agar lebih jelas, bisa dipelajari dan dijadikan contoh kepada pembaca secara teknis maupun prakstis untuk kedepannya. Metode penelitian yang digunakan dalam penelitian ini adalah metode studi kasus. Hodgetts \& Stolte (2003) Hal ini dimaksudkan agar peneliti dapat mengetahui hal unik bagaimana pola komunikasi keluarga yang dilakukan orang tua dan anaknya di kalangan keluarga TNI yang ditinggal tugas operasi yang mengharsukan mereka berpsiah beberapa waktu.

Subjek penelitian yang digunakan dalam penelitian ini adalah anak dari anggota TNI$\mathrm{AD}$ angkatan 89 (Desta \& Pilar ' 89 ) yang memiliki 2 kriteria utama yaitu berumur lebih dari 18 tahun dan pernah ditinggal tugas operasi oleh orang tua minimal 1 tahun kerja. Disini saya menggunakan purposive sampling yaitu suatu teknik penentuan sampel dengan pertimbangan tertentu atau seleksi khusus sesuai dengan kriteria yang ada, saya menggambil minimal 5 narasumber dengan ktiteria tersebut.

\section{Hasil Penelitian dan Pembahasan}

Analisa dapat dilakukan ketika setelah semua data yang di peroleh dan diperlukan terkumpul agar untuk memastikan apakah data-data tersebut sudah dapat menjawab permasalahn pada penelitian ini. Pada tahap pertama, penulis melakukan pra-research sebelum menetapkan kerangka penelitian. Pra-research telah dilaksanakan dengan menyebarkan

Google Form yang menanyakan kondisi saat ditinggal kan dan juga berapa lamanya hubungan jarak jauh dengan orang tua dilakukan. Data primer dalam penelitian ini merupakan hasil wawancara mendalam yang dilakukan secara tatap muka terhadap key informan inti yang lebih lama mengalami hubungan jarak jauh tersebut dan memiliki umur yang cukup dan anak pertama yang dapat diandalkan oleh orang tua, dan 4 (empat) orang informan pendukung. Penulis menetapkan kriteria informan penelitian yaitu:

Tabel 1. Data Key Informan Penelitian

\begin{tabular}{|c|l|c|c|c|}
\hline No. & \multicolumn{1}{|c|}{ Nama } & Usia & $\begin{array}{c}\text { Latar Belakang } \\
\text { Pendidikan }\end{array}$ & Waktu Wawancara \\
\hline 1. & Habsy Jabbar Ramadhan Assidiq & 27 tahun & Dokter & Selasa, 21 September 2021 \\
\hline 2. & Atiqah Noor Amalia Lestari & 19 tahun & Mahasiswi & Selasa, 21 September 2021 \\
\hline 3. & Anggita Ayu Galuh Tejaningrum & 21 tahun & Mahasiswa & Selasa, 21 September 2021 \\
\hline 4. & Aulia Rahmatika Mawardani & 20 tahun & Mahasiswa & Selasa, 21 September 2021 \\
\hline 5. & Desshandra Garsya Dewi & 22 tahun & Mahasiswa & Jumat, 24 September 2021 \\
\hline
\end{tabular}

Sumber : Olahan Peneliti 


\section{Pola Komunikasi Dengan Orang Tua}

Ada beberapa perbedaan dalam gaya pengasuhan yang dilakukan pengasuh dengan setiap orang tua. Gaya pengasuhan juga tergantung pada beberapa pengalaman orang tua sendiri dan pemahaman tentang kapan tahun ini sekitar tahun 1927 saat ini mempengaruhi kaum muda. Pola komunikasi ini memiliki tujuan berbeda yang diharapkan orang tua dari setiap anaknya. Jika komunikasi lancar, terbuka dan dua arah, tidak ada kesalahpahaman di antara komunikator. Pola komunikasi yang setara di antara anak-anak yang diharapkan tidak hanya untuk mereka yang memiliki keluarga militer, tetapi untuk semua anak di seluruh dunia. Seiring kemajuan zaman teknologi, keterbukaan dan pengertian orang tua membuat anak-anaknya betah di rumah, membuat mereka acuh tak acuh terhadap masa depan mereka.

Narasumber banyak mengatakan komunikasi yang dilakukan mereka terhadap orang tua mereka cukup baik walau dalam keadaan ditinggal tugas. Narasumber banyak mengatakan ratarata lebih nyaman berkomunikasi dengan ibu dibandingkan dengan ayah karena adanya sosok yang tegas dan lebih pendiam. Dan bagaimana penerapan komuniasi yang menggunakan beberapa model komunikasi yaitu model komunikasi sederajat demokratis, model komunikasi berimbang berbeda, model komunikasi berlainan tak seimbang, model komunikasi eksklusif atau otoriter.

Banyak yang beranggapan kalau anak tantara itu mandiri, hidupnya enak, dan banyak di fasilitasi dengan orang tua. Tetapi perlu diketahui pola pemberian atau cara berkomunikasi yang dilakukan oleh beberapa anggota TNI sangat berbeda dari biasanya, memiliki orang tua yang baik ketika diajak berdiskusi, atau bahkan menyampaikan pesan secara santai bahkan friendly, menjadikan seorang anak merasa didengarkan dalam hal penyampaian pesan atau perasaan.

\section{Komunikasi Yang Dilakukan Oleh Orang Tua Selama Ditinggal.}

Dalam hal komunikasi jarak jauh, ada beberapa perbedaan yang dibuat orang tua terhadap anakanak mereka. Dilihat dari hasil wawancara, beberapa orang tua acuh tak acuh terhadap kepribadian mereka, sementara yang lain sangat perhatian dan memiliki hubungan yang sangat baik dengan anak-anak mereka dan seluruh keluarga. Anak-anak yang mengharapkan sikap penuh perhatian dan ingin meningkatkan kehadiran orang tua mereka juga mempengaruhi komunikasi yang terjalin.

Memiliki orang tua yang otoriter membuat komunikasi menjadi sulit karena banyaknya perbedaan pendapat yang jarang diselesaikan dengan baik atau tidak adanya komunikasi yang baik antara orang tua dan anak. Sementara itu, anak-anak yang orang tuanya menggunakan komunikasi yang adil dapat lebih banyak mendengar dan berbicara dengan sepenuh hati dan jiwanya untuk memiliki komunikasi dua arah yang baik dan jelas. Dalam hal ini, orang tua personel militer mungkin juga memiliki beberapa jenis atau pola komunikasi yang tidak otoriter kepada keluarga, tetapi sifat orang yang mempengaruhi komunikasi yang baik dan benar adalah kepribadian.

Ada beberapa hal yang cukup menarik saat pembahasan tentang bagaimana komunikasi yang dilakukan oleh masing-masing anggota keluarga yang saya wawancara. Ada beberapa yang merasa nyaman saat melakukan komunikasi yang intens dan aja juga yang merasa cuek akan keadaan sekitar. Selama ditinggal itu juga ada sifat-sifat yang membentuk kepribadian anak akibat komunikasi yang dianggap tidak lancar. Tetapi bagaimanapun memiliki ayah seorang tentara tetap menanamkan sikap yang harus sesuai dengan aturannya, ketika ada beberapa hal yang serius dan mungkin membutuhkan komunikasi secara intens.

\section{Komunikasi Keluarga Penting Dilakukan Dalam Kalangan Keluarga TNI Desta'89.}

Dalam hal ini, komunikasi orang tua anak sangat penting dan juga berkaitan dengan bagaimana pola komunikasi orang tua mengarah pada fakta bahwa pesan yang disampaikan sudah tepat. Pentingnya komunikasi sebagai pionir dan jembatan dari segala pesan yang ingin disampaikan orang tua kepada anaknya yang sedang tumbuh. Anak merasa memiliki kemampuan untuk melakukan segala sesuatu yang dilakukan orang tuanya untuk pertama kali, seperti berinteraksi dengan masyarakat dan lingkungan, dan ingin memikirkan apa yang harus dilakukan dari orang 
tuanya serta menerima pendapat dan solusi. Sikap dan perilaku orang tua juga dapat mempengaruhi cara mereka berkomunikasi dengan anggota keluarga lainnya. Pola-pola yang ditentukan oleh sifat-sifat tersebut tidak semuanya berjalan mulus karena sifat-sifat masingmasing keluarga sangat berbeda. Oleh karena itu, orang tua juga perlu bijak dalam menentukan pola komunikasi yang digunakan. Memiliki hubungan komunikasi yang baik mempengaruhi berbagai hal yang dapat menjadikan tumbuh kembang anak. Dampak signifikan yang terjadi ketika pola komunikasi telah diterapkan kepada anak, diketahui melalui sikap anak, cara berkomunikasi, kesopanan dalam berbicara, dan lain sebagainya.

Adapula dampak positif dan negatif dari pola komunikasi yang telak dipilih oleh orang tua. Dampak positif dari itu banyak orangtua yang bersikap lebih memperhatikan lagi apa yang diinginkan keluarga sehingga tidak terjadi sesuatu hal yang tidak diinginkan. Penyataan dari para narasumber yang memperikan pendapatnya tentang efek atau dampak positif dan juga negatif terhapa pola komuniaksi yang telah orang tua mereka berikan selama ini

\section{Kesimpulan}

Komunikasi merupakan aspek penting dalam kehidupan manusia. Dalam hal penentuan pola komunikasi orang tua terhadap anak dan juga lingkup keluarga sangat berpengaruh. Profesi sebagai tentara yang banyak meninggalkan keluarga demi tugas tidak menutup kemungkinan bagi dia untuk menjalin komunikasi yang baik dengan keluarga. Walaupun Pendidikan tantara yang terkenal keras dan otoriter tidak menjadikan keharusan dalam mengatur pola komunikasi dalam keluarga, banyak yang menggunakan kebebasan tetapi tetap dalam control untuk mengatur dan menyampaikan pesan terutama kepada anaknya. Sesuai dengan tujuan penelitian yang terdapat dalam BAB I dan hasil dari penelitian ini, maka terdapat beberapa poin yang dapat disimpulkan yakni :

1. Mengetahui pola komunikasi dengan orang tua yang selama ini telah diberikan sudah sesuai dengan tumbuh kembang anak di jaman modern dan juga ketepatan komunikasi yang dilakukan orang tua saat ditinggal tugas ataupun tatap muka. Juga adanya keiinginan anak untuk orang tuanya memilik pola komunikasi yang tepat.

2. Mengetahui komunikasi yang dilakukan oleh orang tua anda selama ditinggal sudah efektif sesuai dengan kegunaannya, dan juga alasan kuat untuk para orangtua meninggalkan keluarga dan mengharuskan berkomunikasi jarak jauh bisa ditolerir karena pentingnya komunikasi tersebut.

3. Mengetahui komunikasi keluarga penting dilakukan dalam kalangan keluarga TNI Desta'89 dikarenakan adanya perbedaan konsep parenting orang tua jaman dahulu dan jaman sekaeang, begitu pula dampak posotif dan negatif dari pola komuniaski keluarga yang telah digunakan.

4. Penangkapan dan juga pemaknaan pesan yang diberikan oleh orang tua dapat di tangkap oleh baik, menjadikan proses pertukaran pesannya lancar dan dua arah. Komunkasi yang baik digunakan akan berdampak baik juga untuk tumbuh kembang anak dalam membentuk karakter, kepribadian atau konsep diri mereka masing-masing.

\section{Acknowledge}

Saya berterima kasih atas artikel ini untuk diri saya sendiri dan orang-orang yang saya sayangi.

\section{Daftar Pustaka}

[1] Aw, Suranto. 2011. Komunikasi Interpersonal. Yogyakarta, Graha Ilmu

[2] Cangara, Hafid. (2007). Pengantar Ilmu Komunikasi Edisi Revisi. Jakarta: Raja Garfindo Persada.

[3] Devito, J.A. 2005. Interpersonal Communication Book. New York. Hunter College Of The City University Of New York.

[4] Dian Komala sari, Avin fadilla helmi. Faktor-faktor penyebab perilaku merokok pada remaja. (Jurnal Penelitian) 2000.

[5] Dinar Nur Eka Suwardani. 2015. Pola Asuh Orang Tua dalam Membentuk Karakter Anak di Keluarga Anggota Militer (TNI): (Studi Komunikasi Keluarga). 
[6] Djamarah, Syaiful Bahri. (2004). Pola Komunikasi Orangtua \& Anak Dalam Keluarga. Jakarta: Rineka Cipta,

[7] Drs. Sunaryo, Mkes. 2004. Psikologi Untuk Keperawatan, Jakarta. Penerbit Buku Kedokteran EGC

[8] Effendy, Onong Uchjana. (2003). Ilmu Teori dan Filsafat Komunikasi. Bandung: PT Citra Aditya Bakti.

[9] Effendy, Onong Uchjana.2001. Ilmu komunikasi Teori dan Praktek. Bandung: PT Remaja Rosda Karya

[10] Gordon, Thomas. (1999). Menjadi Orangtua Efektif. Jakarta: Gramedia Pustaka Utama

[11] Gunarsa, Singgih, D. (2001). Psikologi Praktis: Anak, Remaja dan Keluarga. Jakarta: Erlangga.

[12] Hardjana, A.M. (2003) Kom.unikasi Intrapersonal dan Interpersonal. Yogyakarta: Kanisius.

[13] Heriyanto, Muh. 2020. Who Are You. Moeh Media Digital

[14] Hurlock, E.B, (2008). Psikologi Perkembangan: Suatu pengantar sepanjang rentang kehidupan (edisi v). Jakarta: Erlangga.

[15] Suranto Aw. (2011). Komunikasi Interpersonal. Edisi Pertama. Yogyakarta: Graha Ilmu Tarsitu.

[16] West, Richard dan Lynn H. Turner. 2008. Pengantar Teori Komunikasi: Analisis dan Aplikasi. Jakarta. Salemba Humanika.

[17] Yatim, D.I dan Irwanto. (1991). Kepribadian, Keluarga dan Narkotika: Tinjauan Sosial Psikologis. Jakarta: Arcan.

[18] Yusuf, Syamsu L. N., M. Pd. (2001). Psikologi Perkembangan Anak Dan Remaja. Bandung. Remaja Rosdakarya. 